\title{
ROZPOČTOVÉ HOSPODÁRENIE OBCÍ V SLOVENSKEJ REPUBLIKE A PODMIENKY JEHO PLÁNOVANIA
}

\section{BUDGET MANAGEMENT OF MUNICIPALITIES IN THE SLOVAK REPUBLIC AND THE CONDITIONS OF ITS PLANNING}

\section{DOC. ING. RadOSLAV KOŽIAK, PHD. \\ ING. PAula BolCÁRovÁ}

\author{
Katedra verejnej ekonomiky a regionálneho rozvoja $\mid$ Dep. of Public Economy and Regional Development \\ Ekonomická fakulta Faculty of Economics \\ Univerzita Mateja Bela v Banskej Bystrici Matej Bel University Banska Bystrica \\ $\bowtie$ Tajovského 10, 97590 Banská Bystrica, Slovak Republic \\ E-mail: radoslav.koziak@umb.sk,paula.bolcarova@umb.sk
}

\begin{abstract}
Anotácia
Predložený príspevok sa zaoberá problematikou rozpočtového hospodárenia, vývoja a zmien podmienok, za ktorých slovenské obce plánujú svoje hospodárenie. Za ciel' si kladie deskripciu a kvantifikáciu rozpočtového hospodárenia obci v Slovenskej republike v sledovanom obdobi rokov 2000 až 2010, následne identifikáciu vývojovej tendencie vybraných zložiek rozpočtového hospodárenia, ako aj celkového hospodárenia obcí a špecifikáciu podmienok a zmien, pri plánovaní rozpočtových príjmov a výdavkov v sledovanom období. Pri spracovani predloženého príspevku sme využili predovšetkým metódu analýzy, syntézy a komparácie dostupných štatistických údajov o rozpočtovom hospodáreni obci v Slovenskej republike, metódu popisnú, pri špecifikácii zákonom stanovených podmienok a ich zmien v súvislosti s rozpočtovým hospodárením, matematicko-štatistické metódy, pri kvantifikácii rozpočtového hospodárenia a identifikácii vývojových trendov niektorých zložiek rozpočtových príjmov a výdavkov, ako aj metódy abstrakcie, indukcie a dedukcie. Nami zámerne zvolené časové obdobie rokov 2000 - 2010 sme vybrali z dvoch dôvodov. V prvom rade je to realizácia niekolkých etáp reformy verejnej správy $v S R$, ako aj z dôvodu negatívneho vplyvu hospodárskej krízy na rozpočtové (predovšetkým daňové) príjmy obcí a miest. Za vyššie uvedených 11 rokov sa podmienky rozpočtového plánovania a hospodárenia zásadným spôsobom menili. Ich objem a štruktúra súvisia najmä s prechodom mnohých kompetencii zo štátnej správy na miestne a regionálne samosprávy. Problémom bolo meškanie fiškálnej decentralizácie, za decentralizáciou kompetencii, ale aj do súčasnosti pretrvávajúce podfinancovanie preneseného výkonu štátnej správy, ktorý sú obce nútené dofinancovat' z vlastných zdrojov. Napriek viacerým negatívnym vplyvom je $z$ analýzy zrejmé, že celkové prijmy i výdavky miestnych samospráv v Slovenskej republike $v$ absolútnom vyjadrení rastú, mierne sa zvyšuje relatívny podiel investičných výdavkov. Zároveň sme však zistili, že stagnujú, mierne klesajú bežné príjmy a zvyšuje sa podiel príjmov kapitálového charakteru, to môže znamenat' jednak zvyšovanie úverového zat’aženia, resp. predaj majetku, z ktorého príjem je jednorazový a už sa do budúcna nebude opakovat'. Tieto skutočnosti sú výzvou pre d'alšie skúmanie, ktoré sme vzhl'adom na limitovaný rozsah príspevku nemohli spracovat'.
\end{abstract}

Kl'účové slová

rozpočet, miestna samospráva, plánovanie, príjmy a výdavky.

\section{Annotation}

The present contribution deals with the problem of financial management and the development and changes in the conditions under which the slovak municipalities plan their economy. It aims description and quantification of the financial management of municipalities in the Slovak Republic in the period 2000 to 2010 followed by the identification of trends in selected components of financial management, as well as the overall management of municipalities and specification of conditions and 
changes in the planning of revenues and expenses during the period. When processing the present paper, we mainly used the method of analysis, synthesis and comparison of available statistical data on financial management of municipalities in the Slovak Republic, descriptive methods, by specifying legal conditions and changes in the budgetary management, mathematical and statistical methods in quantifying the financial management and identifying trends of certain components of revenues and expenses, as well as abstraction, induction and deduction methods. The time period from 2000 to 2010 was chosen for two reasons. First reason, it is the realization of several phases of public administration reform in Slovakia, as well as because of the negative impact of the economic crisis on the budget (mainly tax) incomes of villages and towns. For above 11 years, the conditions for financial planning and management fundamentally changed. Their volume and structure are mainly related to the transition of many competencies from government to local and regional authorities. The problem was late fiscal decentralization, but also to the persistent underfunding transferred state administration to municipalities is forced to bring in their own resources. Despite a number of negative effects is evident from the analysis that the total revenues and costs of local governments in the Slovak Republic are growing in absolute terms, slightly increasing the relative share of investment spending. At the same time, we found that current incomes stagnate, slightly decreasing and increases the share of income of a capital nature, it can mean both increasing loan burden, respectively, sale of property, from which income is disposable and never to be repeated in the future. These facts are a challenge for further investigation. We could not analyze them, because of limited extent of the contribution.

Key words

budget, local self-government, planning, incomes and costs.

JEL classification: $R 51$

\section{Úvod}

Turbulentné obdobie po roku 1990, kedy dochádza k revitalizácii miestnej samosprávy nielen v Slovenskej republiky, je charakteristické špecifikáciou a relatívne častými zmenami podmienok, za ktorých hospodária a plnia si svoje povinnosti slovenské obce. Množstvo zmien, od roku 2000 v súvislosti s reformou verejnej správy, vytvorením druhého stupňa územnej samosprávy, resp. zmenou podmienok rozpočtového hospodárenia, sú dôvodom, prečo sme sa rozhodli, prehl'adne a globálne, analyzovat' rozpočtové hospodárenie obcí v Slovenskej republike od roku 2000. Práve reforma verejnej správy znamenala významný krok a zároveň zásah, do kompetencií, zodpovednosti, ale najmä do majetkovej základne a rozpočtového hospodárenia miestnej i regionálnej samosprávy na Slovensku. Vzhl'adom na rôzny dátum „vzniku“ a fungovania miestnej a regionálnej úrovne územnej samosprávy, abstrahujeme od rozpočtového hospodárenia vyšších územných celkov a svoju pozornost' upriamime len na najnižšiu úroveň samosprávy - teda na municipality (obce a mestá). Z hl'adiska rozdelenia municipalít na obce a obce so štatútom mesta nerobíme rozdiely, nakol'ko sa na rozpočtové hospodárenia pozeráme čisto z globálneho, celoslovenského hl'adiska, zároveň si však uvedomujeme potrebu, pozriet' sa detailnejšie na rozpočtové hospodárenie a jeho plánovanie špecificky v malých obciach (najmä obce do 1000 obyvatel'ov) a vo vel'kých obciach, najmä mestách, nakol'ko podmienky, možnosti i determinanty tohto procesu sú značne odlišné. Túto skutočnost' berieme ako výzvu pre d’alšie skúmanie, a to najmä v súvislosti s diskusiou o efektívnosti územných samospráv v Slovenskej republike, v súvislosti s procesom municipalizácie, tzn. zníženia počtu administratívnych jednotiek $\mathrm{v}$ podobe, $\mathrm{v}$ akej ich poznáme dnes.

\section{Ciel' a metódy}

Ciel’om predloženého príspevku, je deskripcia a kvantifikácia rozpočtového hospodárenia obcí v Slovenskej republike v sledovanom období rokov 2000 až 2010 (s ohl'adom na dostupnost' štatistických dát Ministerstva financií Slovenskej republiky), následne identifikácia vývojovej 
tendencie vybraných zložiek rozpočtového hospodárenia, ako aj celkového hospodárenia obcí a špecifikácia podmienok a zmien, pri plánovaní rozpočtových príjmov a výdavkov v sledovanom období.

Pri spracovaní predloženého príspevku sme využili predovšetkým metódu analýzy, syntézy a komparácie dostupných štatistických údajov o rozpočtovom hospodárení obcí v Slovenskej republike, metódu popisnú, pri špecifikácii zákonom stanovených podmienok a ich zmien v súvislosti s rozpočtovým hospodárením, matematicko-štatistické metódy, pri kvantifikácii rozpočtového hospodárenia a identifikácii vývojových trendov niektorých zložiek rozpočtových príjmov a výdavkov, ako aj abstrakcie, indukcie a dedukcie.

\section{Výsledky}

Ako už bolo spomenuté vyššie, územná samospráva si chtiac-nechtiac musela prejst' zásadnými zmenami podmienok, za ktorých vykonáva svoje kompetencie, nakladá so svojim majetkom a hospodári podla svojho rozpočtu. V analyzovanom období rokov 2000 až 2010, ktoré sme vybrali zámerne, došlo k implementácii niekol'kých etáp reformy verejnej správy. Jednotlivé etapy znamenali viac peňazí, majetku, kompetencií i zodpovednosti, ale aj viac vrások na čelách poslancov, starostov a primátorov, ktoré im pribudli v súvislosti so zabezpečením jednak originálnych, ale aj prenesených pôsobností, nakol'ko štát presunul s týmito kompetenciami neadekvátne množstvo finančných zdrojov. Nie je tak v tomto období výnimkou, že prenesený výkon štátnej správy v konkrétnej oblasti, musí byt' dofinancovaný z vlastných zdrojov samosprávy, pretože fiškálna decentralizácia nie je dostatočná, no za výkon takýchto kompetencií nesie zodpovednost' samotná municipalita. Krátky prehl'ad najdôležitejších zmien v súvislosti s reformou verejnej správy na Slovensku v predmetnom období, ponúkame v nasledujúcom texte.

\section{Reforma verejnej správy v Slovenskej republike a jej etapy}

Po roku 1990, kedy začíname opätovne hovorit’ o samospráve obcí a miest v pravom slova zmysle, bol vytvorený len najnižší stupeň územnej samosprávy, teda miestna samospráva. Výhl’adovo sa však počítalo s tým, že bude vytvorený i druhý, regionálny stupeň, čo je zakotvené i v Ústave Slovenskej republiky. K tomu však došlo so značným oneskorením. Predpokladom začatia komplexnej reformy verejnej správy na Slovensku bolo prijatie zákona SNR č. 369/1990 o obecnom zriadení. Zákon NR SR č. 221/1996 Z. z. o územnom a správnom usporiadaní Slovenskej republiky, ustanovil sídla 8 krajov, sídla okresov a príslušnost' jednotlivých obcí $\mathrm{k}$ nim. $\mathrm{V}$ tejto fáze ešte nedošlo $\mathrm{k}$ decentralizácii štátnej správy a prechodu kompetencií.

V rokoch 2001 až 2003 dochádza k vytvoreniu samosprávy vyšších územných celkov, pričom na Slovensku hovoríme o tzv. symetrickom modely, tzn. vytvorilo 8 samosprávnych krajov, identických so štátnou správou, čiže s 8 krajskými úradmi. Základom ich vzniku bolo prijatie zákona NR SR č. 302/2001 Z. z. o samospráve vyšších územných celkov. V rokoch 2001 až 2004 postupne dochádza $\mathrm{k}$ zásadnej zmene, nakol'ko sa napín̆a hlavné motto reformy verejnej správy a dochádza $\mathrm{k}$ presunu niektorých pôsobností z orgánov štátnej správy na orgány miestnej a regionálne samosprávy, pričom výhl'adovo sa počíta so zrušením okresných úradov a vybudovaní sústavy špecializovanej miestnej štátnej správy. V tomto období však zatial' nedošlo $\mathrm{k}$ fiškálnej decentralizácii a situácia s novými kompetenciami bola riešená formou decentralizačnej dotácie, ktorej zavedenie bolo dočasné/prechodné. Táto skutočnost' sa výrazne prejavila na štruktúre príjmov obcí na Slovensku, čo dokumentuje analytická čast' nášho príspevku. Klúčcvým v tejto oblasti bol zákon NR SR č. 416/2001 Z. z. o prechode niektorých pôsobností z orgánov štátnej správy na obce a vyššie územné celky.

Ďalšou etapou reformy verejnej správy bola fiškálna decentralizácia, vynútená prechodom kompetencií. V tejto oblasti boli prijaté viaceré právne predpisy, bez ktorých by jej realizácia nebola možná. Jedná sa o zákon NR SR č. 582/2004 Z. z. o miestnych daniach a miestnom poplatku za komunálne odpady a drobné stavebné odpady, zákon NR SR č. 523/2004 Z. z. o rozpočtových pravidlách verejnej správy, zákon NR SR č. 583/2004 Z. z. o rozpočtových pravidlách územnej samosprávy, o rozpočtovom určení daňového výnosu dane z príjmov a zákon NR SR č. 564/2004 Z. z. 
o rozpočtovom určení výnosu dane z príjmov územnej samospráve. Všetky uvedené právne predpisy vstúpili do platnosti od 1. 1. 2005. Prijatím týchto zákonov sa do praxe uvádza jediná podielová dan̆ daň z príjmu fyzických osôb a menia sa miestne dane a obligatórny poplatok za komunálne odpady a drobné stavebné odpady. Zároveň sa ruší decentralizačná dotácia ako prechodné opatrenie na financovanie originálnych kompetencií, zostáva však účelová dotácia/transfer na prenesený výkon štátnej správy, nakol'ko tejto časti kompetencií sa fiškálna decentralizácia netýkala. Pôvodne podielové dane - cestná dan̆ a dan̆ z príjmu právnických osôb sa zmenili, daň z motorových vozidiel je miestnou daňou vyššieho územného celku a daň z príjmu právnických osôb plynie v plnom rozsahu do štátneho rozpočtu.

Od roku 2005 do súčasnosti už v miestnej ani regionálnej samospráve nedošlo k významnejším zmenám, tie možno pozorovat' len v štátnej správe. Vzhl'adom na obmedzený rozsah príspevku sa im podrobnejšie nebudeme venovat' a sústredíme sa na vývoj rozpočtového hospodárenia v rokoch 2000 až 2010.

\section{Rozpočtové hospodárenie obcí v Slovenskej republike}

Z hl'adiska kontinuity sledovaného 11 ročného obdobia je potrebné konštatovat' dve zásadné zmeny. Prvou je zákonom stanovené rozdelenia rozpočtu na bežný a kapitálový, ako aj zavedenie príjmových a výdavkových finančných operácií od roku 2005. Druhou zmenou je zavedenie tzv. programového rozpočtovania, ktorého analýza však nie je predmetom nášho skúmania, preto sa jej v d’alšom texte nebudeme venovat'. V tabul'ke 1 prezentujeme vybrané a pre potreby spracovania tohto príspevku najdôležitejšie zložky rozpočtového hospodárenia slovenských obcí.

Tab. 1: Vybrané zložky príjmov obcí v Slovenskej republike

\begin{tabular}{|c|c|c|c|c|c|c|c|c|c|c|c|}
\hline Údaje v tis. $€$ & 2000 & 2001 & 2002 & 2003 & 2004 & 2005 & 2006 & 2007 & 2008 & 2009 & 2010 \\
\hline $\begin{array}{l}\text { Daňové } \\
\text { príjmy }\end{array}$ & 424856,7 & 464460,7 & 560678,3 & 590799,1 & 655148,9 & 1210024,6 & 1354105,9 & 1442083,3 & 1685268,5 & 1620306,2 & 1421927,0 \\
\hline $\begin{array}{l}\text { Dan̆ } \\
\text { príjmov FO }\end{array}$ & 213774,3 & 228657,2 & 241913,5 & 258884,3 & 278879,9 & 879798,2 & 1001204,8 & 1075751,8 & 1292003,6 & 1206767,0 & 995163,0 \\
\hline $\begin{array}{l}\text { Daň } z \\
\text { príjmov PO }\end{array}$ & 40719,6 & 50302,8 & 61457,2 & 52417,6 & 73444,8 & 0,0 & 0,0 & 0,0 & 0,0 & 0,0 & 0,0 \\
\hline $\begin{array}{lr}\text { Daň } & \text { z } \\
\text { nehnutel'ností }\end{array}$ & 119524,6 & 122468,4 & 123349,7 & 125939,2 & 140953,0 & 207223,0 & 223017,1 & 227477,9 & 237419,5 & 254814,1 & 266284,0 \\
\hline $\begin{array}{l}\text { Nedaňové } \\
\text { príjmy }\end{array}$ & 354896,2 & 362636,5 & 393830,2 & 434954,8 & 253559,4 & 272993,4 & 286418,3 & 327614,0 & 344788,6 & 314245,7 & 327185,0 \\
\hline 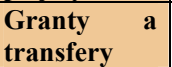 & 124124,7 & 158445,6 & 761101,5 & 1130101,6 & 939474,7 & 632546,6 & 676236,2 & 707299,3 & 727753,4 & 871876,5 & 915273,0 \\
\hline
\end{tabular}

Zdroj: vlastné spracovanie podl'a štátnych záverečných účtov SR za roky 2000 až 2010.

Z tabul'ky 1 je zrejmá zásadná zmena v prípade dane z príjmov právnických osôb. Výnos z nej sa stal od roku 2005 výlučne príjmom štátneho rozpočtu SR, pričom do roku 2004 to bola jedna z troch podielových daní. $Z$ tabul'ky samotnej, ale aj z grafu 1 však možno identifikovat' aj inú dôležitú skutočnost'. Daň z nehnutel'ností je najdôležitejším, stabilným a jediným kontinuálne rastúcim príjmom do rozpočtov obcí v Slovenskej republike. Aj ked’ nárast daňového výnosu nie je nijako dramatický, za jej nespornú výhodu považujeme jej stabilitu. 
Graf 1: Vybrané zložky príjmov obcí v Slovenskej republike

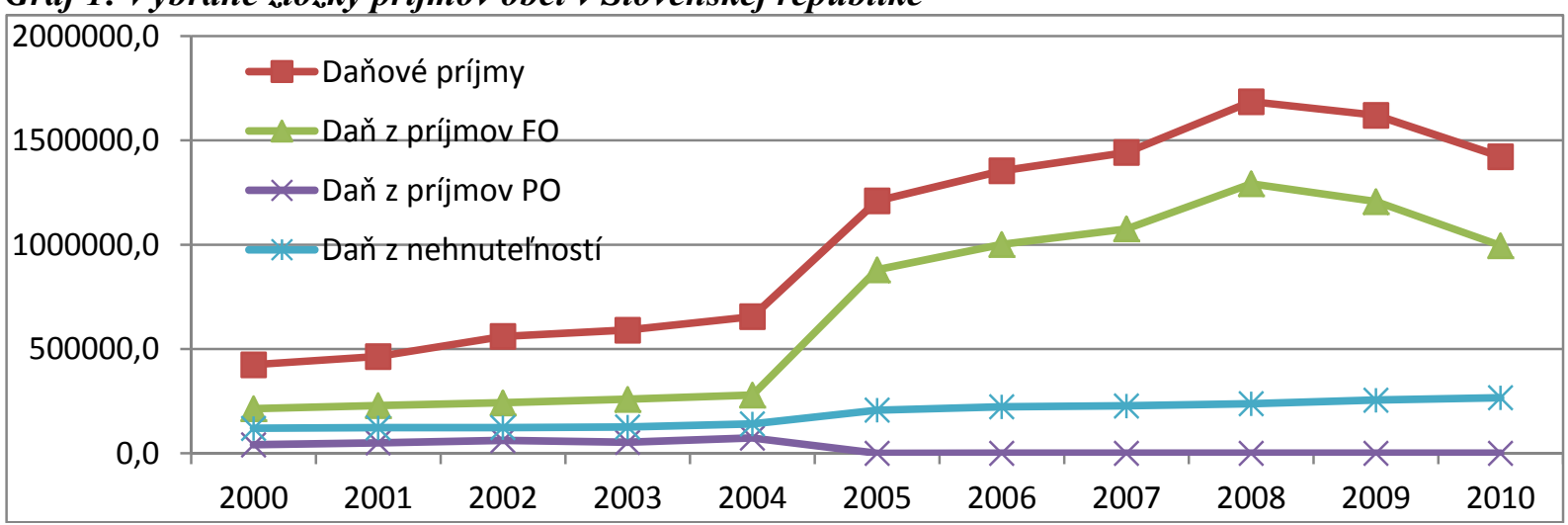

Zdroj: vlastné spracovanie podl'a štátnych záverečných účtov SR za roky 2000 až 2010.

Z grafu 1 je tiež zrejmé, že celkové daňové príjmy korelujú s výnosom dane z príjmov fyzických osôb. Od roku 2005 do roku 2008 je to pre miestne samosprávy dobrá správa, avšak obrat nastáva vplyvom svetovej krízy v roku 2009. Tu zaznamenávame absolútny pokles výnosu a samosprávneho podielu tejto dane, ktorý kontinuálne pokračuje aj v roku 2010. Relevantné údaje za rok 2011 sme žial' nedokázali získat', kvôli absencii dostupnosti štátneho záverečného účtu.

Graf 2: Nedaňové prijjmy, granty a transfery obcí v Slovenskej republike

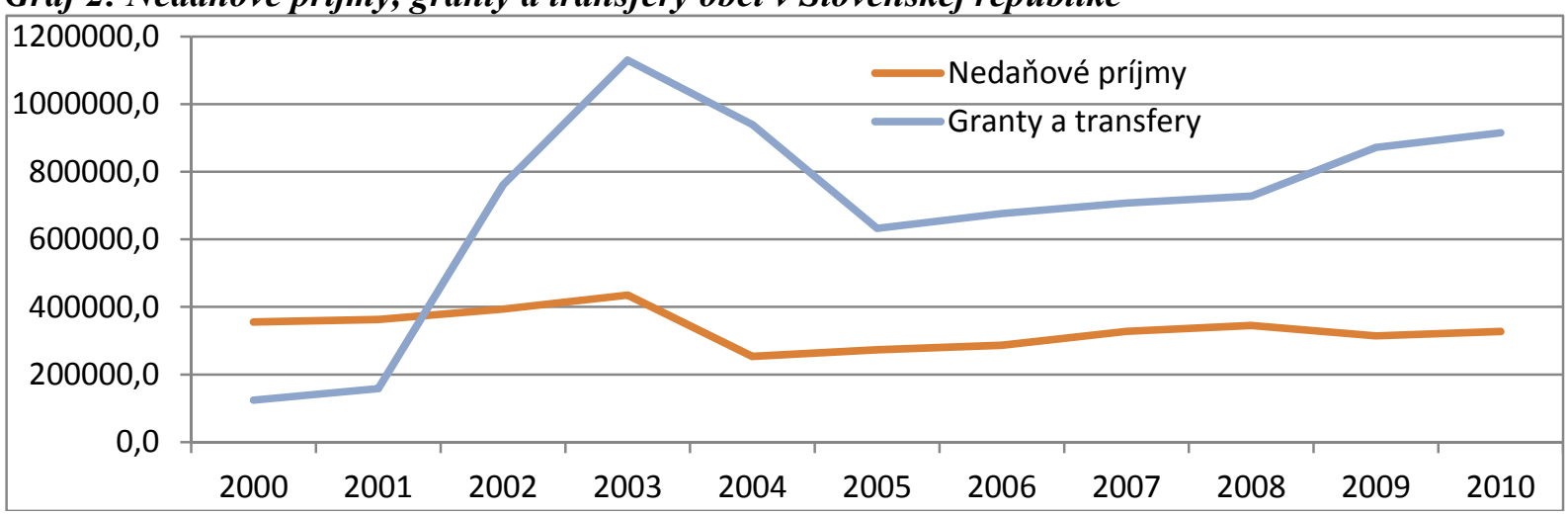

Zdroj: vlastné spracovanie podl'a štátnych záverečných účtov SR za roky 2000 až 2010.

$\mathrm{Z}$ tabul'ky 1, ako aj z grafu 2 je zrejmý rastúci podiel a význam grantov a transferov, ktoré plynú do rozpočtov municipalít zo štátneho rozpočtu Slovenskej republiky. Ich zanedbatel'ná úroveň z roku 2000 sa radikálne zmenila už v roku 2002, pričom najvyššiu absolútnu hodnotu dosiahla táto položka v roku 2003, čo súvisí s poskytovaním tzv. decentralizačnej dotácie obciam, pred implementáciou fiškálnej decentralizácie. Od roku 2005, odkedy je v platnosti fiškálna decentralizácia však položka grantov a transferov nestráca na význame, ked’že ňou sú financované tzv. prenesené pôsobnosti zo štátnej správy na samosprávu. Pokial' by tomu tak nebolo, transfery by sa vrátili na hodnoty z roku 2000 a 2001. Od roku 2008 zaznamenávame po niekol'ko ročnej stagnácii, opätovná nárast grantov a transferov, čo kauzálne súvisí aj s globálnou hospodárskou krízou a určitou mierou kompenzácie zo strany štátu vo vzt’ahu k miestnym samosprávam, ktoré v tomto období zaznamenali významný prepad podielu na výnose dane $\mathrm{z}$ príjmu fyzických osôb. Vývoj nedaňových príjmov je stabilný počas celých 11 rokov sledovaného obdobia, s miernym výkyvom nadol a následným rastom v roku 2004. Súvis vidíme s reformou verejnej správy, ktorá zmenila takmer všetky miestne poplatky na miestne dane, pričom jediným nedaňovým poplatkom sa stal poplatok na komunálne odpady.

Do tabul'ky 2 sme zosumarizovali prehl'ad bežných, kapitálových a celkových príjmov miestnych samospráv od roku 2000 do roku 2010. Vzhl'adom na zákonnú úpravu a jej zmenu od roku 2004, uvádzame klasifikáciu na bežné a kapitálové príjmy až od tohto roku. Podobne je to i čo sa týka príjmových finančných operácií. 
Tab. 2: Hlavné zložky rozpočtových príjmov obcí v Slovenskej republike

\begin{tabular}{|c|c|c|c|c|c|c|c|c|c|c|c|}
\hline Údaje v tis. $€$ & 2000 & 2001 & 2002 & 2003 & 2004 & 2005 & 2006 & 2007 & 2008 & 2009 & 2010 \\
\hline Bežné príjmy & $\mathrm{n}$ & $\mathrm{n}$ & $\mathrm{n}$ & $\mathrm{n}$ & $\begin{array}{c}1848183 \\
0 \\
\end{array}$ & $\begin{array}{c}2115564, \\
6 \\
\end{array}$ & $\begin{array}{c}2316760, \\
5 \\
\end{array}$ & $\begin{array}{c}2476996, \\
6 \\
\end{array}$ & $\begin{array}{c}2757810 \\
5 \\
\end{array}$ & $\begin{array}{c}2806428 \\
4 \\
\end{array}$ & $\begin{array}{c}2664385, \\
0 \\
\end{array}$ \\
\hline $\begin{array}{l}\text { Kapitálové } \\
\text { príjmy }\end{array}$ & $\mathrm{n}$ & $\mathrm{n}$ & $\mathrm{n}$ & $\mathrm{n}$ & 302374,9 & 413227,8 & 442341,1 & 416122,3 & 477245,6 & 376235,5 & 622648,0 \\
\hline $\begin{array}{l}\text { Finančné } \\
\text { operácie } \\
\text { príjmové }\end{array}$ & $\mathrm{n}$ & $\mathrm{n}$ & $\mathrm{n}$ & $\mathrm{n}$ & 379513,0 & 306290,2 & 540861,9 & 305772,4 & 371254,1 & 575670,4 & 728630,0 \\
\hline Príjmy spolu & 1117219,8 & $\begin{array}{c}1086040, \\
6\end{array}$ & $\begin{array}{c}1908307 \\
4\end{array}$ & $\begin{array}{c}2334309 \\
9\end{array}$ & $\begin{array}{c}2530070 \\
9\end{array}$ & $\begin{array}{c}2835082 \\
7\end{array}$ & $\begin{array}{c}3299963, \\
5\end{array}$ & $\begin{array}{c}3198891, \\
3\end{array}$ & $\begin{array}{c}3606310 \\
2\end{array}$ & $\begin{array}{c}3758334 \\
3\end{array}$ & $\begin{array}{c}4015663, \\
0\end{array}$ \\
\hline
\end{tabular}

Zdroj: vlastné spracovanie podl'a štátnych záverečných účtov SR za roky 2000 až 2010.

Pre názornejšiu ilustráciu celkového vývoja, ponúkame graf 3.

\section{Graf 3: Hlavné zložky rozpočtových príjmov obcí v Slovenskej republike}

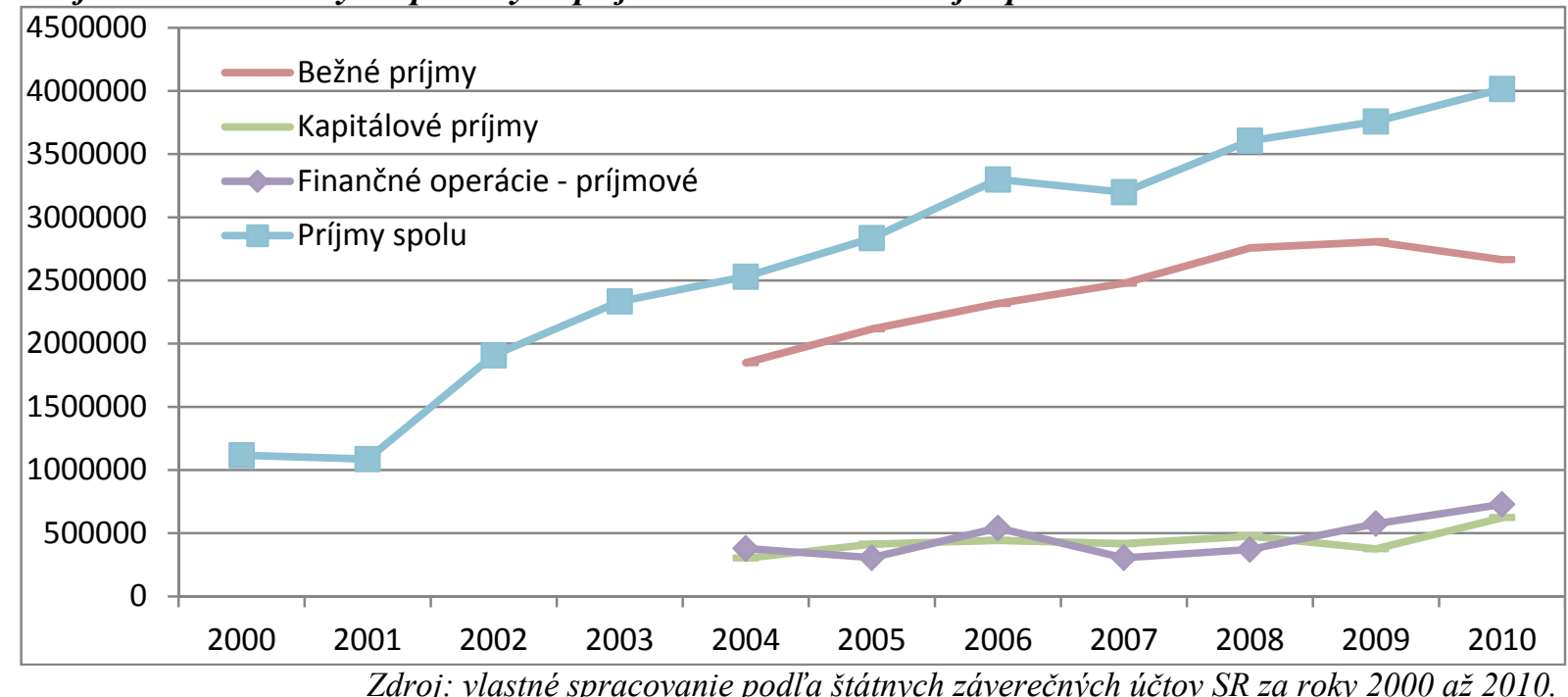

Reforma verejnej správy prebiehajúca od roku 2001, významne zvýšila príjmy do rozpočtov miestnych samospráv na Slovensku. Ich nárast je zrejmý už v porovnaní rokov 2001 a 2002, pričom s výnimkou roku 2007, kontinuálne pokračuje až do roku 2010. Nepochybne najdôležitejšou zložkou celkových príjmov, sú príjmy bežného charakteru, avšak zmenu trendu zaznamenávame v roku 2010, kedy relatívny podiel bežných príjmov klesá, pričom klesá aj absolútny príjem do rozpočtov obcí vSR. Tento úbytok je kompenzovaný rastom kapitálových príjmov a zvýšenými finančnými operáciami. Naznačuje to možné riziko „prejedania“ jednorazových kapitálových príjmov, predajom majetku, alebo prijímaním úverových zdrojov, napriek tomu, že zákon nepripúšt’a použit investičné zdroje na prevádzku.

V snahe poskytnút' čitatel'ovi komplexnejší prehl'ad o rozpočtovom hospodárení slovenských obcí za obdobie rokov 2000 až 2010, ponúkame v nasledujúcom texte stručnú analýzu výdavkov. Tie sú k dispozícii v štruktúre bežné a kapitálové už od začiatku sledovaného obdobia. (Vid’ tab. 3 a graf 4.)

Tab. 3: Hlavné zložky rozpočtových výdavkov obcí v Slovenskej republike

\begin{tabular}{|c|c|c|c|c|c|c|c|c|c|c|c|}
\hline Údaje v tis. $€$ & 2000 & 2001 & 2002 & 2003 & 2004 & 2005 & 2006 & 2007 & 2008 & 2009 & 2010 \\
\hline $\begin{array}{l}\text { Bežné } \\
\text { výdavky }\end{array}$ & 622307,3 & 659672,1 & 1138944,2 & 1648037,9 & 1727935,9 & 1862295,0 & 2069918,2 & 2196760,3 & 2413775,5 & 2543810,8 & 2577978,0 \\
\hline $\begin{array}{l}\text { Kapitálové } \\
\text { výdavky }\end{array}$ & 244520,2 & 290581,5 & 532081,2 & 405040,8 & 449402,4 & 630555,0 & 771834,4 & 688840,2 & 765415,3 & 860168,9 & 1105384,0 \\
\hline $\begin{array}{l}\text { Finančné } \\
\text { operácie } \\
\text { výdavkové }\end{array}$ & $\mathrm{n}$ & $\mathrm{n}$ & $\mathrm{n}$ & $\mathrm{n}$ & 111614,9 & 136619,5 & 255751,7 & 135119,2 & 164628,6 & 138650,5 & 209293,0 \\
\hline $\begin{array}{l}\text { Výdavky } \\
\text { spolu }\end{array}$ & 1049250,4 & 1015261,4 & 1774627,2 & 2287210,6 & 2288953,2 & 2629469,6 & 3097504,3 & 3020719,6 & 3343819,3 & 3542630,2 & 3892655,0 \\
\hline
\end{tabular}


Celkové výdavky slovenských miestnych samospráv majú stabilne rastúci charakter, najdynamickejšie sú z logických dôvodov v rokoch 2001 až 2003, avšak ich rast pokračuje i v d’alšom období. Pozoruhodné je, že ho nepribrzdila ani hospodárska kríza, čo naznačuje čerpanie rezerv, resp. vyššiu dynamiku rastu kapitálových výdavkov, na grafe zobrazených svetlo zelenou farbou, pričom v prípade bežných výdavkov zaznamenávame najmä v rokoch 2008 až 2010 stagnáciu. Výdavkové finančné operácie, cez ktoré sa realizuje najmä splácanie prijatých úverových zdrojov, je počas rokov 2004 až 2010 na stabilne nízkej úrovni. To by malo znamenat', že nedochádza $\mathrm{k}$ vyššiemu zadlžovanie obcí a miest, čo ovplyvnil aj zákon o rozpočtových pravidlách územnej samosprávy, ktorý limituje celkový dlh obce, ako aj výdavky na dlhovú službu v danom roku. Nemôžeme však dokázat', ani vyvrátit', či nejde o dlhodobejšie úverové zdroje, ktoré sa splácaním a teda zvýšenými výdavkovými finančnými operáciami neprejavia v d’alších rokoch.

Graf 4: Hlavné zložky rozpočtových výdavkov obcí v Slovenskej republike

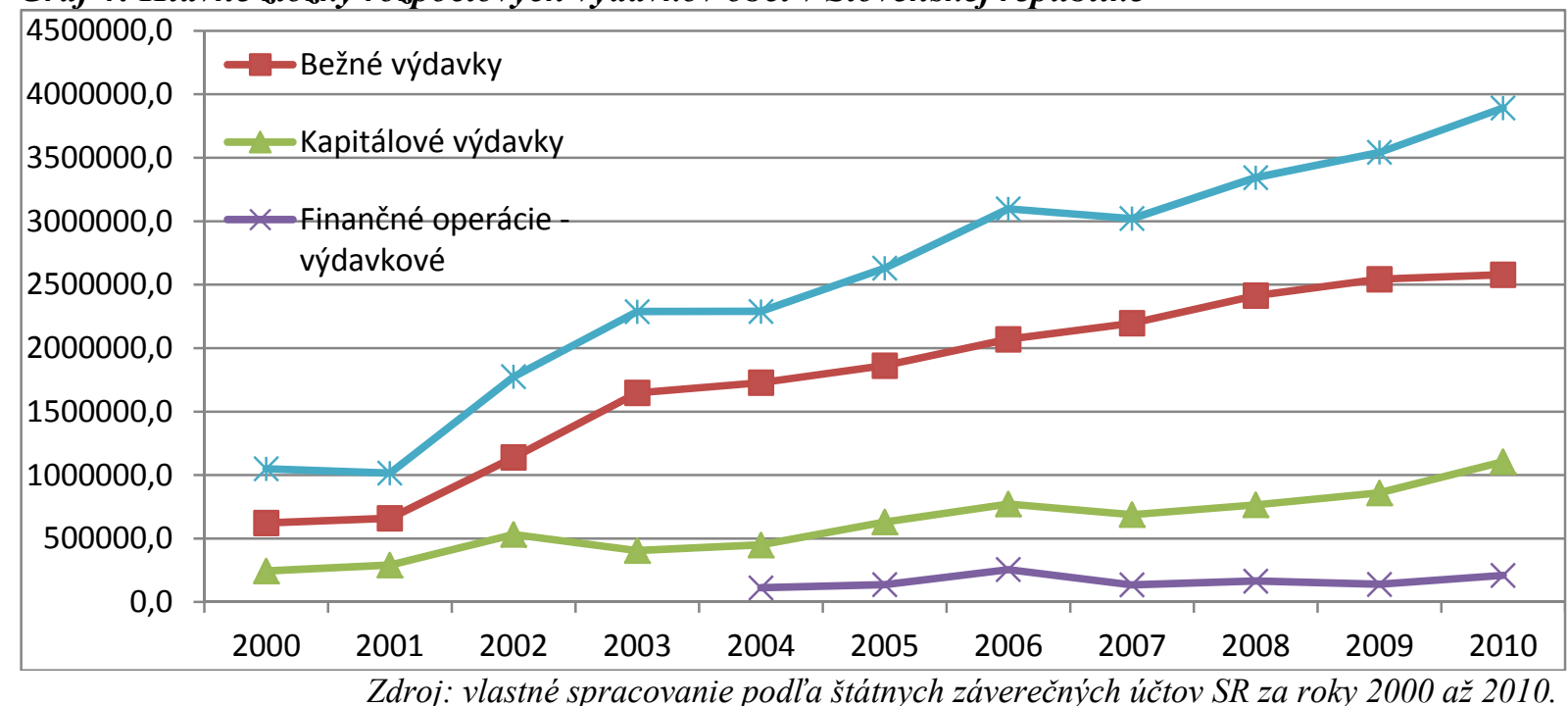

Na záver nášho príspevku ešte ponúkame čisto ilustračný vývoj celkového výsledku rozpočtového hospodárenia v obciach na Slovensku, ktorý sumarizuje bežný i kapitálový rozpočet, ako aj finančné operácie a naznačuje, že v globále slovenské municipality hospodária s prebytkovými rozpočtami, čo v prípade bilancie bežných príjmov a výdavkov vyžaduje zákon o rozpočtových pravidlách územnej samosprávy, pripúšt’a len schodkový kapitálový rozpočte po splnení stanovených podmienok.

Graf 4: Výsledok hospodárenia obcí v Slovenskej republike

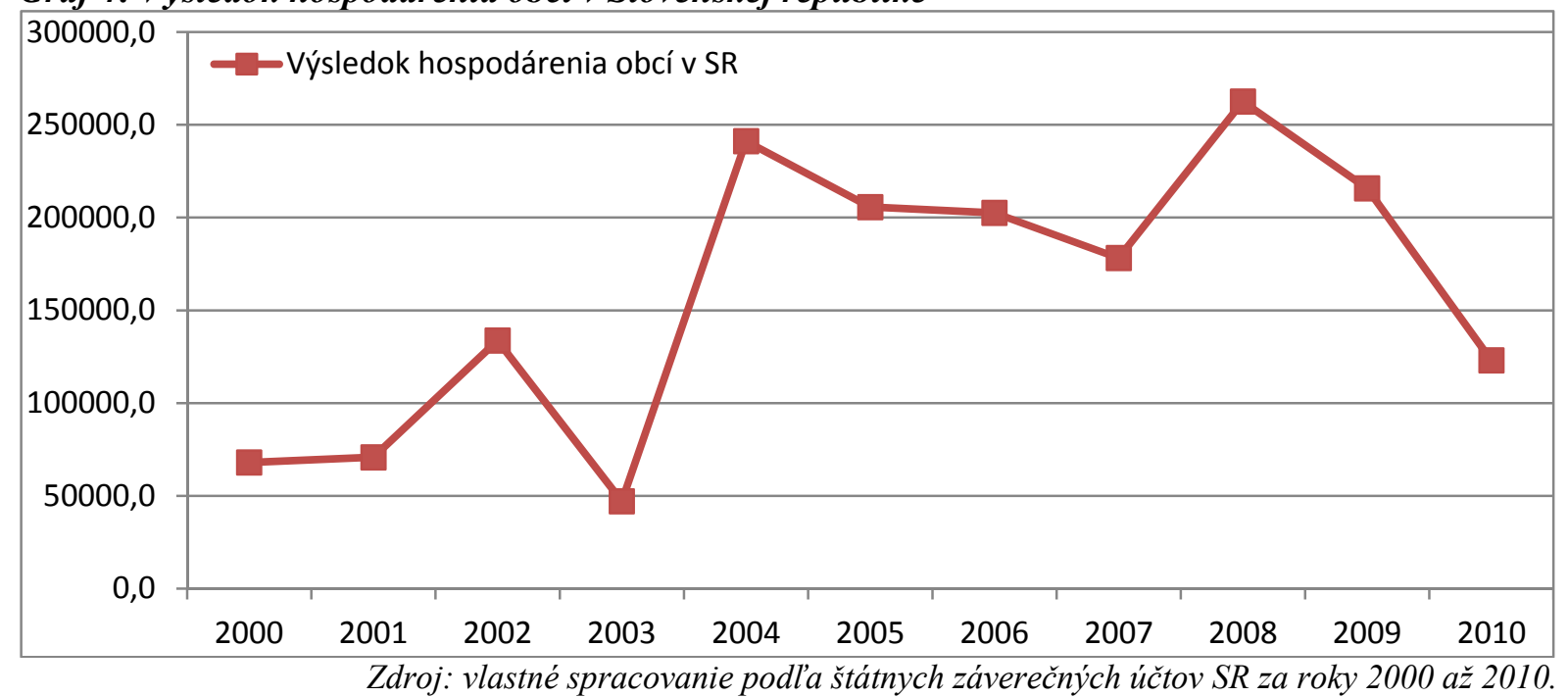


Z grafu 4 vyplýva, že celkový výsledok rozpočtového hospodárenia obcí v Slovenskej republike, dosahuje každoročne kladnú hodnotu. V jednotlivých rokoch je však tento výsledok rozličný, kolísavý. Nie je preto možné identifikovat' jednoznačný vývojový trend. Čo však zo štatistických údajov vyplýva, je sklon $\mathrm{k}$ zníženiu výšky prebytku rozpočtového hospodárenia v rokoch 2008 až 2010. To naznačuje, že vplyvom hospodárskej krízy obce jednak hl'adajú rezervy svojho hospodárenia, sú nútené šetrit', ale zároveň možno dedukovat', že ich hospodárenie využíva rezervu, vytvorenú v priaznivejšom predchádzajúcom období, kedy bol výnos podielovej dane z príjmu fyzických osôb do ich rozpočtov vyšší.

\section{Záver}

V predloženom príspevku sme sa zaoberali problematikou rozpočtového hospodárenia a stavom a zmenami podmienok, za akých slovenské municipality plánujú svoje hospodárenie. Jedná sa o obdobie, charakteristické významnými zmenami, ale aj o obdobie, pre ktoré je typický silný vplyv hospodárskej krízy, čo sa negatívne prejavilo predovšetkým v znížení absolútneho výnosu dane z príjmov fyzických osôb, ktorá je aktuálne jedinou podielovou daňou v SR. Obce a mestá sa s touto situáciou museli vysporiadat'. Pravdou je, že štát vzhl'adom na nepriaznivý vývoj výnosu tejto dane, pomohol obciam vyššími transfermi zo štátneho rozpočtu, tie však daňový výpadok nepokryli.

„Môžeme konštatovat', že v sledovanom období sa značne zvýšil fiškálny význam miestnych rozpočtov a ich vplyv na stav verejných financií v SR. Uskutočnené systémové zmeny sa výrazne prejavili v rozpočtovom hospodárení miestnych samospráv a do vel'kej miery ovplyvnili príjmovú základňu, ako aj výdavkové potreby jednotlivých miestnych samospráv." (Flaška, 2008, s. 4)

Analyzované obdobie sme zvolili aj preto, že v rokoch 2001 až 2005 prebehlo niekol'ko etáp reformy verejnej správy, pričom zmena legislatívneho prostredia a s tým súvisiaca zmena podmienok, za ktorých slovenské miestne samosprávy existujú, plnia kompetencie, plánujú a hospodária, významne ovplyvnila každodenný život v samospráve. K zmene došlo z hl’adiska štruktúry i objemu príjmov, výdavkov, ale aj podmienok, za ktorých si samosprávy môžu zriad'ovat' a zakladat' iné právnické osoby. Faktom však zostáva, že municipality vplyvom reformy verejnej správy, no i na vzdory negatívneho dopadu hospodárskej krízy, $\mathrm{v}$ bežných cenách kontinuálne zvyšujú svoje celkové výdavky. Za pozitívum však považujeme fakt, že bežné výdavky v posledných rokoch sledovaného obdobia stagnujú, mierne rastú výdavky investičného charakteru, čo by malo do budúcna priniest' ovocie, nielen v oblasti rozpočtového hospodárenia.

\section{Literatúra}

[1] FLAŠKA, F. Faktory determinujúce príjmovú základňu a výdavkové potreby miestnych samospráv. In Scienta Iuventa - zborník príspevkov. Banská Bystrica: Ekonomická fakulta Univerzity Mateja Bela v Banskej Bystrici, 2008. 8 s. ISBN 978-80-8083-582-8.

[2] KOŽIAK, R. Zmierňovanie regionálnych disparit prostredníctvom regionálnej politiky. Banská Bystrica: Ekonomická fakulta Univerzity Mateja Bela, 2008. 138 s. ISBN 978-80-8083-573-6.

[3] Štátne záverečné účty SR za roky 2000 - 2010 [online]. [cit. 15. 04. 2013] Dostupné z: $<$ http://www.finance.gov.sk/Default.aspx?CatID=3557>.

Př̀spěvek byl zpracován v rámci grantu VEGA 71/1010/2011 „Teoreticko-metodologické východiská plánovania v podmienkach územných samospráv a možnosti ich aplikácie v SR“. 